\title{
Dr John Thomas Arlidge and Victorian Occupational Medicine
}

\author{
CLARE HOLDSWORTH*
}

In 1892 Dr John Thomas Arlidge, physician at the North Staffordshire Infirmary, published The hygiene, diseases and mortality of occupations. ${ }^{1}$ This lengthy volumeover 550 pages-was the first significant British publication on occupational diseases since Charles Turner Thackrah's The effects of the principal arts, trades and professions, . . . on health and longevity, published in $1831 .^{2}$ Hygiene made Arlidge the leading latenineteenth-century authority on occupational diseases. The book was based principally on his experience of observing and treating occupational diseases-particularly those of potters-during his appointments at the North Staffordshire Infirmary and as Factory Certifying Surgeon for Stoke-on-Trent. His contribution to occupational medicine also included leadership of the Association of Certifying Medical Officers (ACMO), ${ }^{3}$ formed in 1868 to represent the interests of Certifying Surgeons. Arlidge was elected as its first and only President, and he dominated the ACMO until its demise ten years later. In the 1890s following the publication of Hygiene, he was also associated with the introduction of health and safety legislation in the pottery industry. ${ }^{4}$

This article addresses Arlidge's contribution to the practice of occupational medicine, especially his leadership of the ACMO, and to the medical understanding of occupational diseases, particularly respiratory diseases of potters. It extends previous accounts of his

*Dr Clare Holdsworth, CCSR, Faculty of Economic and Social Studies, University of Manchester, Dover Street, Manchester M13 9PL.

The research for this paper was supported by a Research Studentship from the University of Liverpool. I would like to thank Bob Woods, Gerry Kearns, John Pickstone and the three anonymous referees for their comments and suggestions; $\mathrm{Dr}$ Alun Davies for advice on locating material on Arlidge; and the North Staffordshire Medical Institute for access to the Arlidge collection.

1 John Thomas Arlidge, The hygiene, diseases and mortality of occupations, London, Percival, 1892.

2 Andrew Meiklejohn, The life, work and times of Charles Turner Thackrah, surgeon and apothecary of Leeds, 1795-1833, Edinburgh and London, Livingstone, 1957.

${ }^{3}$ Stephen Huzzard, 'The role of the certifying surgeon in the state regulation of child labour and industrial health 1833-1973', MA thesis, University of Manchester, 1977.
4 On these regulations see: Peter Bartrip, 'Expertise and the dangerous trades, 1875-1900', in R MacLeod (ed.), Government and expertise specialists, administrators and professionals, 1860-1919, Cambridge University Press, 1988, pp. 89-109; Barbara Harrison, 'Suffer the working day: women in the "dangerous trades", 1880-1914', Women's Stud. int. Forum, 1990, 13: 79-90. On the introduction of legislation in the pottery industry see: Andrew Meiklejohn, 'The successful prevention of lead poisoning in the glazing of earthenware in the North Staffordshire Potteries', Br. J. ind. Med., 1963, 20: 169-80; idem, 'The successful prevention of silicosis among china biscuit workers in the North Staffordshire Potteries', Br. J. ind. Med., 1963, 20: 253-63; D Evans and A Jones, 'The development of statutory safeguards against pneumoconiosis and lead poisoning in the North Staffordshire pottery industry', Ann. Occupational Hyg., 1974, 17: 1-14; and Clare Holdsworth, 'Potters' rot and plumbism: occupational health in the North Staffordshire pottery industry', $\mathrm{PhD}$ thesis, University of Liverpool, 1995. 


\section{Dr J T Arlidge and Victorian Occupational Medicine}

career, which have concentrated on his significance in North Staffordshire, by considering also his national reputation and his impact on the early-twentieth-century occupational health specialists who developed the discipline after his death in $1899 .^{5}$

\section{Mid-Nineteenth-Century Occupational Medicine}

Though the association between work and health was recognized by factory reformers from the beginning of the nineteenth century, the development of occupational medicine was somewhat sporadic. ${ }^{6}$ Nineteenth-century factory legislation was introduced to address employers' responsibilities towards three classes of workers: children, young workers and women. ${ }^{7}$ Their predicament was the result of long working hours, lack of education and general insanitary working conditions, and it was to these issues that factory reformers devoted their attention. The concerns of present-day occupational health specialists, that is exposure to industrial hazards such as dust and toxins, were often of secondary importance; from a twentieth-century perspective occupational medicine remained "stillborn in the age of sanitary reform". ${ }^{8}$ The contribution of doctors to debates on work and health was often overshadowed by other interests. As Robert Gray suggests, the introduction of early factory legislation was mediated by powerful interest groups: operatives, employers, politicians and servants of the state. ${ }^{9}$ Some doctors contributed to one side or the other of the factory legislation debate (Thackrah in particular was a keen supporter of factory reform and was associated with the 10 hours movement in the 1830s), ${ }^{10}$ but for the most part they remained advisers to the principal interest groups, rather than key players. ${ }^{11}$

The legislation introduced did little to encourage doctors to investigate the causes of industrial ill-health. Though they were appointed as Certifying Surgeons from 1833 onwards, this was strictly to uphold the law on the age at which children could be employed. ${ }^{12}$ A few Certifying Surgeons were retained as factory doctors by larger employers, but they were usually attracted by the financial rewards rather than by the opportunity to specialize in the treatment of occupational diseases. ${ }^{13}$ There was often strong competition for posts, particularly as they provided a potentially lucrative way of

5 Elliot Isaacson, The forgotten physician, Newcastle-under-Lyme, no date; V Hibbert, 'Dr John Thomas Arlidge 1822-99; with special reference to his life in the potteries', dissertation in part fulfilment of BA degree, University of Keele, 1975; E Posner, 'John Thomas Arlidge (1822-99) and the Potteries', Br. J. ind. Med., 1973, 30: 266-70; Edward Myers, 'J. T. Arlidge (1822-1899): a disillusioned alienist', Psychiatr. Bull., 1995, 19: 770-2.

6 Robert Gray, 'Medical men, industrial labour and the state in Britain 1830-1850', Soc. Hist., 1991, 16: 19-43; Anthony Wohl, Endangered lives: public health in Victorian Britain, London, J M Dent, 1983, ch. 10; William R Lee, 'The emergence of occupational medicine in Victorian times', Br. J. ind. Med., 1947, 4: 1-29.

7 Gray, op. cit., note 6 above.

8 William R Lee, 'Robert Baker: the first doctor in the Factory Department', Br. J. ind. Med., 1964, 21: 85-63, 167-79, p. 176.

${ }^{9}$ Gray, op. cit., note 6 above, p. 41.

$10 \mathrm{~J}$ Cleeland and S Burt, "Charles Turner Thackrah: a pioneer in the field of occupational health', Occupational Med., 1995, 45: 285-97.

11 Gray, op. cit., note 6 above, p. 41.

12 The requirement for all children to have a certificate signed by any medical practitioner was introduced in 1833. The factory inspectors appointed to administer the legislation immediately pointed out the desirability of appointing qualified physicians or surgeons to act as Certifying Surgeons to reduce the opportunities for fraudulent certification from unqualified persons. In 1844 the law was changed to appoint Certifying Surgeons to this post. Huzzard, op. cit., note 3 above, pp. 23-4.

13 Ibid., p. 44. 


\section{Clare Holdsworth}

extending private practices among factory owners. ${ }^{14}$ Many Certifying Surgeons held additional public appointments to bolster their income. The post of Certifying Surgeon did not, therefore, provide a basis from which a specialization in occupational diseases could easily be developed. Only a small number of local doctors who practised in industrial centres inquired into the causes of occupational diseases. Most notably two Sheffield doctors, G C Holland and J C Hall, investigated the incidence of respiratory disease among grinders in the 1850 s. $^{15}$ Hence, as Gray concludes, mid-nineteenth-century occupational medicine lacked a "secure institutional base". 16

From the mid-nineteenth century onwards the most important contribution to the development of occupational medicine came from government-sponsored surveys. In 1860 John Simon, then Medical Officer at the Privy Council, appointed Edward Greenhow to conduct an inquiry into respiratory diseases in industrial centres. ${ }^{17}$ Greenhow carried out investigations in thirty-three industrial towns, covering branches of the textile, mining, earthenware, smelting, and instrument-making industries. ${ }^{18}$ The health of pottery workers featured prominently in these surveys, as they suffered one of the highest mortality rates from respiratory disease. Greenhow calculated that pottery workers in the two urban registration districts of the Potteries, Stoke and Wolstanton, had a far higher death rate from phthisis and other respiratory diseases than the local population as a whole. ${ }^{19}$ Around one-third of men in both districts were employed in the pottery industry in 1851, yet between 1855 and 1859 potters accounted for half of all deaths in Stoke and 40 per cent in Wolstanton. Conversely miners, who accounted for 10 and 20 per cent of the adult population in Stoke and Wolstanton respectively, contributed only 8 and 13 per cent of respiratory deaths in each district. ${ }^{20}$ Greenhow concluded from his analysis that

In inquiring into the causes of excessive mortality from pulmonary diseases among the male inhabitants of these districts, the rest of the population may therefore be put out of the question, and attention be exclusively directed to the circumstances connected with the manufacture of earthenware. ${ }^{21}$

Simon drew on Greenhow's research to press for special legislation on the problems of over-crowding and poor ventilation in factories. He also commissioned further inquiries into trades using arsenic, phosphorus, lead and mercury. ${ }^{22}$ In 1864 in his Sixth Report as Medical Officer to the Privy Council, Simon summarized the results of these inquiries, renewing his call for legislative intervention to reduce the incidence of occupational disease. ${ }^{23}$ As a consequence of Simon's reports, the 1864 Factory Act included a clause requiring ventilation in factories. ${ }^{24}$ The 1867 Factory Extension Act took this principle

\footnotetext{
14 Ibid., p. 44; Anne Digby, Making a medical living: doctors and patients in the English market for medicine, 1720-1911, Cambridge University Press, 1994, pp. 120-2.

15 Sidney Pollard, A history of labour in Sheffield, Liverpool University Press, 1959, p. 62.

16 Gray, op. cit., note 6 above, p. 33.

17 Wohl, op. cit., note 6 above; Royston Lambert, Sir John Simon 1816-1904 and English social administration, London, MacGibbon \& Kee, 1963, pp. 331-5.

18 PP 1861 xvI (Cd. 161), Third report of the
}

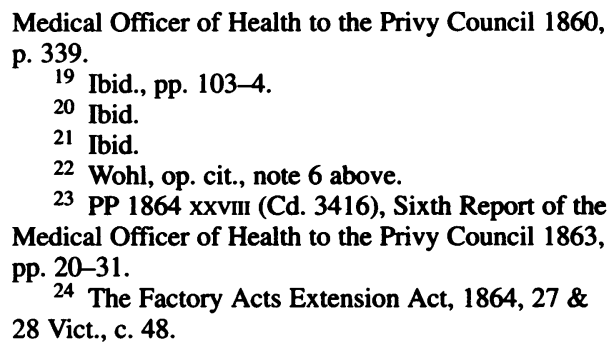

Medical Officer of Health to the Privy Council 1860,

20 Ibid.

21 Ibid.

22 Wohl, op. cit., note 6 above.

23 PP 1864 xxvIII (Cd. 3416), Sixth Report of the Medical Officer of Health to the Privy Council 1863, p. 20-31.

28 Vict., c. 48 


\section{Dr J T Arlidge and Victorian Occupational Medicine}

further, requiring a mechanical fan in workshops where inhalation of dust was a danger to health. ${ }^{25}$

At the same time as Greenhow was carrying out his surveys, William Farr, at the office of the Registrar General, introduced a occupational classification for the 1861 Census. ${ }^{26}$ This was specifically designed to allow the computation of occupational mortality rates and was based on the premise that the most important characteristic of an occupation was the materials used in carrying it out. ${ }^{27}$ Hence, Farr sought to group together occupations with similar exposure risks, an approach that reflected his concern in identifying the "medical and moral" consequences of working with particular materials, rather than with their social and economic base. ${ }^{28}$ Occupational mortality rates were published in the Registrar General's decennial supplement from 1851-60 onwards.

Simon's and Farr's interest in the relationship between occupation and health increased awareness of the incidence and principal causes of occupational diseases. Simon, in particular, regarded occupational medicine as a important part of public health medicine and it was this tradition that influenced Arlidge when he first arrived in North Staffordshire.

\section{Occupational Health in North Staffordshire}

Arlidge moved to North Staffordshire in 1862 at the age of forty, after having been elected to the post of Physician at the North Staffordshire Infirmary. He established himself in the market town of Newcastle-under-Lyme, west of Stoke. ${ }^{29}$ His medical career had begun as apprentice to a general practitioner in Rochester, Kent, after which he moved to London to read medicine at King's. He then specialized in mental diseases, studying for at time at the Middlesex Lunatic Asylum, before taking up an appointment at St Luke's Hospital. ${ }^{30}$ Here his work was influenced by the alienist approach to treating mental illness. ${ }^{31} \mathrm{He}$ developed more humanitarian treatments for the mentally ill and was instrumental in bringing about the abolition of patients' mechanical restraints. ${ }^{32}$ His final appointment in London was as a general physician at the West London Hospital, where he wrote a treatise entitled The state of lunacy, dedicated to the 7th Earl of Shaftesbury. ${ }^{33}$ His move to North Staffordshire in 1862 not only marked a change in location but also a break with his previous interest in mental health. It is unclear why Arlidge chose to go to Stoke-he was offered a similar post in Sunderland and the Chair of Medicine at Melbourne - and there is no evidence of a family association with the area. It is likely though, that he was unhappy about the way that asylum psychiatry was developing and could not see a future for himself in the London hospitals. ${ }^{34}$

\footnotetext{
25 The Factory Acts Extension Act, 1867, 30 \& 31 Vict., c. 103. See Wohl, op. cit., note 6 above, p. 263.

26 William Farr, 'The new classification of the people according to their employments', Appendix to PP 1863 LiII (Cd. 3221), General report of the census of 1861, Pt 1, pp. 225-48.

27 Ibid.

28 Edward Higgs, 'Disease, febrile poisons and statistics: the census as medical survey, 1841-1911', Soc. Hist. Med., 1991, 4: 465-78, p. 472.
}

29 Isaacson, op. cit., note 5 above.

30 Ibid.

31 Myers, op. cit., note 5 above.

32 Ibid.

33 Ibid. Shaftesbury was a prominent supporter of non-restraint for lunacy patients, which was adopted by the Metropolitan Commissioners in the 1840s. Geoffrey Finlayson, The seventh Earl of Shaftesbury, 1801-1885, London, Eyre Methuen, 1981, pp. 229-33.

34 Myers, op. cit., in note 5 above. 


\section{Clare Holdsworth}

At the time of his arrival in Stoke the incidence of ill-health among potters, as illustrated by Greenhow's research, was the subject of both national and local concern. Arlidge's appointment at the North Staffordshire Infirmary gave him ample opportunity to study the influence of employment on health; many of the patients were pottery workers and the hospital was partly funded out of workers', or establishment, subscriptions, collected by the employer and paid to the Infirmary. ${ }^{35}$ In return, each employer received a number of tickets, based on the total subscription, which he could use to nominate employees for treatment. At the time that Arlidge joined the staff of the Infirmary, establishment subscriptions accounted for two-thirds of the hospital's income. ${ }^{36}$ Arlidge complained that the hospital functioned mostly as a "medical relief club" for the workpeople, an arrangement he found "very inequitable" to both the Infirmary's medical staff and other practitioners in the area, who were deprived of income from better paid workers who would otherwise be treated as private patients. ${ }^{37}$

In 1862 potters' health became the subject of local debate when twenty-six leading manufacturers issued a petition supporting Shaftesbury's call for an inquiry into the employment of children and young persons not covered by existing factory legislation. ${ }^{38}$ After one year's residence in the Potteries, Arlidge was summoned to give evidence to the Commissioners appointed to investigate the possibility of extending the Factory Acts to the pottery industry. He had already formed a strong impression of the character of its residents:

The potters as a class, both men and women, but more especially the former, represent a degenerated population, both physically and morally. They are as a rule stunted in growth, ill-shaped, and frequently ill-formed in the chest; they become prematurely old, and are certainly short lived; they are phlegmatic and bloodless, and exhibit their debility of constitution by obstinate attacks of dyspepsia, and disorders of the liver and kidneys, and by rheumatism. But of all diseases they are especially prone to chest disease, to pneumonia, phthisis, bronchitis, and asthma or potter's consumption. ${ }^{39}$

Arlidge continued that he was in favour of restricting the employment of young children, in line with the majority of his medical colleagues. His strongly-worded statement drew a

35 Establishment subscriptions were introduced in 1816 . In 1823 the scheme was extended to enable a worker's family to receive treatment through establishment subscriptions, providing they themselves were not employed; see North Staffordshire Infirmary, 'An address to the working classes', in Report of the annual general meeting 1816, North Staffordshire Medical Institute, and 14 November 1823, North Staffordshire Infirmary committee book 1814-1825, North Staffordshire Medical Institute. The level of workers' subscriptions introduced in 1816 was not less than 1 penny for workers earning more than 18 shillings a week, half a penny for workers earning 7 to 18 shillings and one farthing for anyone earning less than 7 shillings a week. A few factories also appointed factory doctors who were paid an annual fee to provide medical treatment. Two firms gave evidence of subscriptions to the 1843 Commission on Children's employment, PP 1843 xIV (Cd. 431), Royal Commission on children's employment, second report (manufacturers), Appendix, witnesses number 87 $\& 55$.

36 North Staffordshire Infirmary, 47th annual report of the North Staffordshire Infirmary 1861-1862, North Staffordshire Medical Institute, p. 7.

37 John Thomas Arlidge, 'On the sanitary state of the Staffordshire Potteries, with especial reference to that of the potters as a class, their mortality, and the diseases prevalent among them', Br. for. med.chir. Rev., 1864, 34: 214-29, p. 227.

38 Marguerite Dupree, Family structure in the Staffordshire Potteries 1840-1880, Oxford, Clarendon Press, 1995, pp. 215-28.

39 PP 1863 XVIII (Cd. 3170), First report of the Royal Commission on Employment of Children in Trades and Manufactories not Regulated by Law, Appendix, p. 24. 


\section{Dr J T Arlidge and Victorian Occupational Medicine}

considerable amount of local attention; opponents of factory reform, predominantly smaller manufacturers, regarded his comments as extreme. ${ }^{40}$ In his defence, Arlidge complained that it was unfair to single him out when his statement and "those of other medical men in the district all point more or less distinctly to the same general conclusions". ${ }^{41}$ Following this inquiry, the pottery industry was included in the schedule for the 1864 Factory Act. ${ }^{42}$ Arlidge was immediately appointed Certifying Surgeon for Stoke to see that the requirements on children's employment were fulfilled. ${ }^{43}$ His role as Certifying Surgeon did not pass without criticism from medical colleagues. Writing in 1920, William Spanton, his colleague at the Infirmary, commented that Arlidge himself was "instrumental in the appointment of factory surgeons". According to Spanton, his action-coupled with his comments on potters' health-greatly offended manufacturers and his medical associates. ${ }^{44}$

Arlidge's initial reaction to the conditions prevalent in the district prompted him to inquire further into the health of the people of North Staffordshire. After only eighteen months residence in the Potteries, he published two articles on its prevailing sanitary conditions. In a pamphlet dated 28 May 1864, he used the Registers of Deaths in Stoke Parish for the year ending 31 March 1863 to examine the town's mortality with respect to age and cause of death. ${ }^{45} \mathrm{He}$ concluded that Stoke's overall mortality at that time was higher than that for England and Wales; in 1861, death rates were 29.5 per 1,000 and 21.6 per 1,000 respectively. He also observed excessive respiratory disease mortality within Stoke parish. Loosely classified, all respiratory diseases accounted for around 40 per cent of total deaths to persons aged ten years and over. ${ }^{46}$ For a subsequent paper published in the British and Foreign Medico-Chirurgical Review of 1864, Arlidge extracted out-patient records from the North Staffordshire Infirmary's patient register, so augmenting his previous analysis of parish death certificates with data relating to potters' morbidity. ${ }^{47} \mathrm{He}$ calculated that out of a sample of 267 potters, both male and female, around two-thirds of men and two-fifths of women had sought medical care as a result of respiratory disease. ${ }^{48}$

Arlidge linked the high rate of potters' respiratory disease with the dusty atmosphere of their workshops, supporting Greenhow's investigations of five years earlier. Greenhow had also provided further evidence on the causal role of dust in potters' respiratory diseases from dissections of various workers' lungs. ${ }^{49} \mathrm{He}$ was able to confirm that flint dust inhaled by potters could lead to silicosis or susceptibility to other respiratory disease, especially phthisis. ${ }^{50}$

40 Dupree, op. cit., note 38 above, pp. 236-7.

41 Staffordshire Sentinel, 8 Oct. 1863.

42 The Factory Acts Extension Act, 1864, 27 \& 28 Vict., c. 48 .

43 PP 1865 xx (Cd. 3473), Report of the Inspector of Factories, for the half year ending 31 st October, 1864, 429, p. 138.

44 William Spanton, The story of my life, London, Connoisseur, 1920, pp. 38-9.

45 John Thomas Arlidge, On the mortality of the parish of Stoke-upon-Trent, with reference to its causes, and the ratio of deaths among children and potters, Hanley Reference Library, Local Pamphlets, vol. $38,1864$.
46 Ibid.

47 Arlidge, op. cit., note 37 above.

48 Ibid., p. 228.

49 Various articles by Edward Greenhow in Transactions of the Pathological Society of London, 1865, 16: 59-61; 1866, 17: 24-27 and 34-6; 1869, 20: 41-59.

50 Ibid., 1866, p. 36. In a dissection of a potter's lung, Greenhow found evidence of tubercle, the presence of which he claimed was promoted by the state of the lungs. 


\section{Clare Holdsworth}

In addition to silica dust, potters who worked in the decorating and dipping shops were also exposed to lead compounds. As only a minority worked with these, the incidence of lead poisoning was lower than that for respiratory disease, but the acute nature of lead poisoning and the profile of its victims-frequently young, unmarried girls-made it a far more emotive issue than silicosis. ${ }^{51}$ Pottery manufacturers (including Josiah Wedgwood) were well aware of the damaging publicity that cases of lead poisoning could have for their trade. ${ }^{52} \mathrm{~A}$ few potters experimented with leadless glazes to reduce the potential risks to both workers and consumers. ${ }^{53}$ In contrast, little was done to reduce exposure to dust; few manufacturers, especially among the smaller firms, were concerned with the incidence of respiratory disease, and most working potters accepted "potters' rot" as a necessary consequence of their trade. ${ }^{54}$ But some larger manufacturers could afford to be paternalistic and address the problem of working conditions; for example, Thomas Twyford built his Cliffe Vale works in 1879 with the devout intent "to remedy the insanitary conditions of all pottery works I have ever known". 55

\section{Association of Certifying Medical Officers}

For Arlidge the association between employment and ill-health which he observed in the course of his duties was too self-evident to be ignored. In particular it brought home to him both the part that occupation played in diagnosing disease and the need for a medical presence in factories to monitor the health of workers. However, he found that the role of Certifying Surgeon was inadequate to meet these requirements. Immediately following his appointment as Certifying Surgeon, Arlidge was given the opportunity to promote his views on the development of a factory medical service, in response to manufacturers' criticisms of Certifying Surgeons for over-charging and making unnecessary visits. ${ }^{56}$ The dispute over the Surgeons' conduct was caught up in the ongoing feud between the two principal Factory Inspectors, Redgrave and Baker: Redgrave was generally hostile to the Surgeons, whilst Baker, a doctor himself, was inclined to support his fellow medical practitioners. ${ }^{57}$ In 1868 , to appease the growing disquiet over their conduct, Baker issued a circular to the Surgeons in his district suggesting that they should provide public evidence of their contribution to improvements in factory conditions. ${ }^{58}$ A group of recently appointed Surgeons, led by Arlidge, immediately responded and announced the first meeting of an Association of Certifying Medical Officers, at which Arlidge gave the Presidential address. ${ }^{59}$ At its inauguration the ACMO attracted 130 members, only a minority of the 800 Certifying Surgeons appointed throughout Great Britain. ${ }^{60}$ In subsequent years membership fell off, leaving the running of the ACMO to a handful of doctors-principally Arlidge.

51 Holdsworth, op. cit, note 4 above, ch. 7.

52 A Finer and G Savage, The selected letters of Josiah Wedgwood, London, Cory, Adams and Mackay, 1965, p. 153.

53 Meiklejohn op. cit., note 4 above.

54 Holdsworth, op. cit, in note 4 above.

55 Diane Baker, Potworks: the industrial architecture of the Staffordshire Potteries, London, Royal Commission on the Historical Monuments of England, 1991, p. 90.

56 Huzzard, op. cit., note 3 above, pp. 59-61.
57 At that time the administration of the Factory Inspectorate was spilt into two regions, with two principal Factory Inspectors: T K Djang, Factory inspection in Great Britain, London, Allen and Unwin, 1942.

58 PP 1868-69 xIV (Cd. 4093-II), Report of the Inspector of Factories, for the half year ending 30th April 1869, 465, p. 203.

59 Huzzard, op. cit., note 3 above, pp. 67-104.

$60 \mathrm{Br}$. med. J., 1868, ii: 57-8. 


\section{Dr J T Arlidge and Victorian Occupational Medicine}

The ACMO set itself two principal aims:

1) The observation and collection of facts tending to promote the advance of sanitary science, and the relief and prevention of disease incident to the various processes of manufacture.

2) The consolidation and improvement of our position in its relation to the Government and the public, and the promotion of the interests of the profession generally in all that relates to state medicine. $^{61}$

Arlidge had more success in directing the members of the Association to secure their own position, than in advancing medical knowledge of occupational diseases. The ACMO was most active during the mid-1870s when the future of certification was considered by the 1876 Royal Commission on Factories. Critics of medical certification claimed that doctors could be dispensed with if rules for the inspection of birth certificates were introduced instead. ${ }^{62}$ In defence of the existing system, Arlidge argued that removing the requirement for medical examination of children would "open the door to a multitude of abuses". Only a medical examination by a suitably qualified person at the factory, in addition to the inspection of birth certificates, would ensure the physical well-being of children and reduce the opportunity for fraudulent employment of those who were under-aged or unfit. ${ }^{63}$ Arlidge also argued that rather than being abolished, the duties of Certifying Surgeons should be extended to include medical examinations of workers exposed to industrial hazards under a proposed scheme for factory medical officers. ${ }^{64}$ The two principal Factory Inspectors were again divided on this issue: Redgrave was only willing to advocate the continuation of Surgeons' examination for all children up to thirteen years of age, whilst Baker preferred that the Surgeons should certify all employees up to sixteen years and supported the suggestion of medical examination of adult workers. ${ }^{65}$ These proposals were considered by the 1876 Royal Commission, to which Arlidge gave evidence as President of the ACMO. ${ }^{66}$ However, the Commission was unsympathetic to the idea of extending the Certifying Surgeon's role and questioned him only on the sanitary condition of the Potteries and his work as a Certifying Surgeon, including how he conducted examinations and the number of refusals of employment issued. ${ }^{67}$

The Surgeons were successful only in securing their position; the 1878 Factory Act, which incorporated the Commission's recommendation, continued the certification of children, but did not extend medical examination to other workers. ${ }^{68}$ The Act also marked the demise of the ACMO; the Surgeons had achieved their principal objective, and there was little enthusiasm to carry on the campaign for medical examinations. ${ }^{69}$ The ACMO's demise also coincided with Arlidge's entry into local politics. In 1876 he was elected as Conservative councillor for Newcastle-under-Lyme Borough west ward and became Mayor for the Borough in $1878 .^{70}$ With local duties taking up much of his time, Arlidge was unable to continue his efforts on behalf of the ACMO; although he does not appear

61 Huzzard, op. cit., note 3 above, p. 72.

62 Ibid.; and Lee, op. cit., note 8 above.

63 John Thomas Arlidge, 'The medical organisation of the Factory Acts', Trans. natn. Ass. Promotion soc. Sci., 1871: 472-80.

64 Ibid.

65 Lee, op. cit., note 8 above.

66 PP 1876 xxx (Cd. 1443-1), Minutes of evidence to the report from the Select Committee on the Factory and Workshops Act 1876, Pt II, pp.

69-76.

67 Ibid.

68 An Act to Consolidate and Amend the Law relating to Factories and Workshop, 1878, 41 \& 42 Vict., c. 16.

69 Huzzard, op. cit., note 3 above.

70 Isaacson, op. cit., note 5 above. 


\section{Clare Holdsworth}

to have devoted as much energy to local politics as he had to the Association. ${ }^{71} \mathrm{He}$ was not noted as a keen attender at council meetings, and no important local improvements were made during his brief tenure as Mayor; though his local standing was increased by his close involvement with the establishment of Newcastle's public library of which he was elected founding President. ${ }^{72} \mathrm{He}$ was also an enthusiastic founder member of the North Staffordshire Field Club and developed a keen interest in local natural history. ${ }^{73}$

\section{The Hygiene, Diseases and Mortality of Occupations}

After the break up of the ACMO and his brief foray into local politics, Arlidge kept a relatively low profile during the $1880 \mathrm{~s}$, but his interest in occupational health continued and in 1887 he was invited to present a series of lectures to operative potters on employment and health. ${ }^{74}$ Two years later, he was granted the greatest honour of his career when invited by the Royal College of Physicians to present the Milroy Lectures for 1889 on 'Occupations and trades in relation to public health' ${ }^{75}$ It was the text of these lectures that Arlidge published in Hygiene, which was a landmark in the development of British occupational medicine. In particular it filled the gap in English medical literature which had developed since Thackrah's death. The absence of a standard treatise on occupational medicine contrasted with France and Germany, where a number of doctors had published books on the subject of occupation and health. ${ }^{76}$

The tradition of British occupational medicine which Arlidge inherited from Simon and Farr was most closely related to public health medicine. Arlidge's title, The hygiene, diseases and mortality of occupations, reflected this tradition, but he was not just concerned with the hygiene of occupational diseases. In his preface, he stated that the main purpose of the book was to illustrate the extent to which all occupations must react upon a worker's "mental and corporeal condition". ${ }^{77}$ Following Thackrah, Arlidge's approach to occupational medicine was to examine the conditions of an occupation and to seek out every possible way in which it could affect health. The role of occupational medicine was then to disentangle those illnesses incidental to an occupation from accidental occurrences, so to aid doctors in the correct diagnosis of occupational diseases and to demonstrate the importance of occupational medicine in general medical practice. He strongly believed that it was essential for a medical man "to acquaint himself with the occupation of a patient",

71 Hibbert, op. cit., note 5 above, p. 29.

72 Ibid., p. 28.

73 Ibid.; and Posner, op. cit., note 5 above, p. 268. According to Posner his term of office was "uneventful". When he stepped down as Mayor he could report only that a new wall had been built for the parish church and that "the sewage question was still a thorn in the side of the Corporation". By the 1870 s the importance of the Borough as the centre of commerce and local political and social life had been overshadowed by the growth of the neighbouring pottery towns. Though there was some altercation between councillors advocating a scheme of improvements and those opposed to burdening the rate-payers, there was very little motivation for change; the sewage system in particular remained decrepit. See F Bealey, 'Municipal politics in Newcastle-under-Lyme 1872-1914', N. Staffs J. Field Stud., 1965, 5: 64-73.

74 John Thomas Arlidge, On the diseases of potters and their causes and prevention, two lectures, delivered by request, at Burslem and Stoke-on-Trent, Hanley, Allbut and Daniel, 1887.

75 Br. med. J. 1889, i: 580-2, 642-44, 702-6, 766-9.

76 Arlidge, op. cit., note 1 above, pp. 6-12. For example see: Ludwig Hirt, Die Krankheiten der Arbeiter, 1871, and Alexandre Layet, Hygiène des professions et des industries, 1875.

77 Arlidge, op. cit., note 1 above, p. ix. 


\section{Dr J T Arlidge and Victorian Occupational Medicine}

in the same way that he would familiarize himself with a patient's home, neighbourhood and family history. ${ }^{78}$ In doing so, a doctor would be able to "arrive at a correct estimate of the part played by employment in producing the symptoms he detects, or in causing the mortality he has to regret". ${ }^{79}$ Hence, rather than a textbook for factory reform, Arlidge intended Hygiene as a medical textbook, and attempted to outline all possible health effects, however trivial, which were associated with occupations; for example, he discussed the risks associated with professional occupations at some length-including those associated with mental labour. ${ }^{80}$ To reinforce the fact that certain occupations carried high mortality rates, he included details on the incidence of industrial diseases based on the Registrar General's published occupational mortality rates and life insurance data. Less attention was given to factory reform-out of the 568 pages only 6 dealt explicitly with hygienethough, where appropriate, the need for improvement in the workplace, particularly factory ventilation, was stressed.

To achieve a complete account of the relationship between work and health, Arlidge needed a suitable classification of occupations. He devised a scheme, based in part on Farr's earlier classification, dividing all occupations into two classes: those unconnected with the manufacturing process, that is not directly concerned with adding to the wealth of the community, and those directly dedicated to augmenting wealth. ${ }^{81}$ Occupations in the second class were then grouped together into etiological groups based on the materials used and exposure to industrial hazards, in line with Farr's earlier classification. Arlidge identified eight groups:

1. The generation of dust.

2. The employment of noxious or poisonous materials.

3. The evolution of noxious vapours.

4. The action of excessive temperatures.

5. The action of electricity.

6. The action of abnormal atmospheric pressure.

7. Excessive use, friction or strain.

8. Exposure to infection and contagion. ${ }^{82}$

Arlidge devoted most attention to the first of these-the generation of dust, which he recognized as the principal cause of occupational ill-health. ${ }^{83}$ Hygiene was published eight years after Koch's discovery of the tubercle bacillus, when the bacteriological principle of respiratory disease dominated medical discourse and inorganic causes of respiratory disease were considered to be less important, ${ }^{84}$ but, for Arlidge, dust remained the primary cause of respiratory disease:

Bronchitis, asthma, fibroid and tubercular consumption occupy a foremost place in the category of causes of British mortality; and without doubt these maladies are largely attributable to the inhalation of dust, operating per se, or in conjunction with constitutional proclivities and insanitary surroundings. ${ }^{85}$

78 Ibid.

79 Ibid.

80 Ibid., p. 90-3.

81 Ibid., p. 67.

82 Ibid., p. 259.

83 Ibid., pp. 245-58.
84 David Rosner and Gerald Markowitz, Deadly dust: silicosis and the politics of occupational disease in twentieth-century America, Princeton University Press, 1991, pp. 15-31.

85 Arlidge, op. cit., note 1 above, p. 245. 


\section{Clare Holdsworth}

His refusal to give up dust as the major cause of occupational respiratory disease was influenced by thirty years of observation of potters' silicosis and the tradition in occupational medicine relating dust to respiratory disease, as exemplified by Greenhow's work. Arlidge concluded that tubercle bacilli would not cause phthisis unless there was an "antecedent change in the vitality of the affected tissue" ${ }^{86} \mathrm{He}$ stated his opinion thus:

I look upon a phthisical lung as one prepared for the germination and multiplication of bacilli, and not a primary product of those microscopic organisms, nor of the products of their organic existence. ...

It must be accepted as a fact that dust induces a malady bearing a strong similitude to tubercular phthisis, and yet that the malady is not tubercular in its actual nature.

In cases of potters' consumption from inhaled dust, occurring under my own observation, bacilli have been sought in vain ... For experience proves that the dust-produced lung disease may co-exist with tubercular phthisis; and, further, that where labour is prosecuted in a dusty atmosphere tubercular mischief, in those constitutionally predisposed to it, is more likely to arise. ${ }^{87}$

Arlidge acknowledged that occupational fibroid diseases and phthisis developed in similar ways; it was extremely difficult to distinguish potters' silicosis from tubercular disease. As an aid to diagnosis, he advised that the cough was harsher among patients with fibrosis and that their features resembled more those of an asthma sufferer, than those of a consumptive. $^{88}$

In Hygiene Arlidge also contributed to the debate on the relationship between mining and health. There was considerable disagreement between doctors as to whether coal dust caused illness, because, according to the Registrar General's returns, miners had a relatively low occupational death rate. ${ }^{89}$ The collection and publication of occupational mortality returns reinforced the opinion that coal mining could be beneficial to health, and that the carbonaceous nature of the dust provided protection against respiratory diseases, particularly phthisis. ${ }^{90}$ However, the calculation of miners' mortality reflected two biases in occupational mortality rates. First, these were based on death certificates which recorded the last job held, leading to an underestimate of the number of deaths in industries such as mining with a high rate of job loss through invalidity. ${ }^{91}$ Second, selection for and during employment created a group of workers in better health than the general population and workers in less strenuous occupations. ${ }^{92}$ Arlidge was well aware of these problems; he pointed out that miners represented a particularly healthy group of people, who benefited from leading an active life and so escaped "the evils of sedentary work". They also had shorter working hours and, according to Arlidge, less opportunity for riotous living than factory workers who lived in the main urban centres. Furthermore, he claimed that protection from coal dust was relevant only for attacks of phthisis, not fibrosis of the lungs. ${ }^{93}$ Arlidge concluded that the assumption that coal dust was beneficial relied too much on occupational mortality rates, as opposed to a proper understanding of the conditions in coal mines.

86 Ibid., p. 245.

87 Ibid., pp. 245-6.

88 Ibid., pp. 310-13.

89 G Rosen, The history of miners' diseases: $a$ medical and social interpretation, New York, Schuman's, 1943, pp. 318-24, and Holdsworth, op. cit., note 4 above, pp. 79-82.
90 Arlidge, op. cit., note 1 above, p. 270.

91 Naomi Williams, The occupational mortality statistics of the General Register Office, 1861-1911, Liverpool Papers in Human Geography, University of Liverpool, Department of Geography, 1990.

92 Ibid.

93 Arlidge, op. cit., in note 1 above, pp. 270-1. 


\section{Dr J T Arlidge and Victorian Occupational Medicine}

In addition to being a textbook for doctors, Arlidge stated that Hygiene could be utilized by workers to choose an occupation best suited to their physical and mental capacities. ${ }^{94}$ He was particularly critical of people who ignored the risks involved and chose employment in dangerous trades, encouraged by the higher wages on offer. He believed that these "feckless" workers were in fact less suited to such hazardous employment than others who were more diligent.

\section{Health and Safety Legislation in the Pottery Industry}

Hygiene clearly reflected Arlidge's talents as a medical scientist and his ability to unravel the complex relationship between work and health. The book was initially a triumph and was reviewed favourably by the press throughout the country. The Times described it as: "a novel and important work dealing with a subject of great public as well as medical interest." 95 For the British Medical Journal, Hygiene. was

an important volume . . . containing a large amount of highly valuable, if necessarily somewhat miscellaneous, information. By the conscientious labour which he has expended upon his task Dr Arlidge has earned the gratitude, not only of his medical brethren, but of legislators and others who are interested in the investigation of the many social and economic questions involved in the statutory regulation of workshops and hours of labour. ${ }^{96}$

Much of the interest that Hygiene generated was due to the popularity of its subject. It was published one year after the 1891 Factory Act, which had authorized the Home Secretary to introduce special rules for trades or processes scheduled as dangerous to life or limb. ${ }^{97}$ The Act marked the beginning of a campaign to reduce the incidence of occupational diseases such as lead, phosphorus and mercury poisoning, by extending legislation to introduce minimum requirements for working conditions and, where possible, to prohibit the use of dangerous substances such as lead. It was led by a number of prominent radicals (including Sir Charles Dilke), Women's Trade Unionists led by Gertrude Tuckwell (Dilke's niece by marriage) and members of the aristocracy, particularly Millicent Sutherland-Leveson-Gower, wife of the 4th Duke of Sutherland, whose husband owned a large part of the Potteries. ${ }^{98}$ Despite Arlidge's intention that Hygiene should aid doctors, it proved to be of greater value for these reformers. The Daily Chronicle, which supported factory reform, made this explicit in its review:

This is in every sense a monumental work, a monument of research and industry, and one that reveals incredible national negligence, a betrayal on an Oriental scale of the primary duty of organised citizens to preserve life and health. Dr Arlidge, without intending it, has described laissezfaire, triumphant, with death and disease walking in its train. ${ }^{99}$

The newspaper followed this up with an account of working conditions in the Potteries. In November 1892 it published a number of articles under the heading 'The Dust Death' detailing the level of exposure to lead and dust in the Potteries. ${ }^{100}$ At the same time, the

94 Ibid., p. 40.

95 The Times, 28 July 1892.

$96 \mathrm{Br}$. med. J., 1892, ii: 847.

97 An Act to amend the Law relating to Factories and Workshops, 1891, 54 \& 55 Vict., c. 75.

98 Holdsworth, op. cit., note 4 above.

99 Daily Chronicle, 26 Sept. 1892.

100 Daily Chronicle, 14 and 24 Nov. 1892. 


\section{Clare Holdsworth}

case for further reform in the industry was made by operative potters in their evidence to the Royal Commission on Labour. ${ }^{101}$

Though Arlidge was not a leading figure in this campaign, his work was used to promote its claims; for example, manufacturers of pottery leadless glazes sought his endorsement for their products. ${ }^{102}$ However, Arlidge himself was not convinced of the need for further reform and believed that the reforms which he had campaigned for in the 1860 s and 1870s were generally sufficient. His political views were those of an Evangelical Tory, as illustrated by his support for Shaftesbury's reforms on lunacy and factory conditions. ${ }^{103}$ Existing factory legislation was consistent with his paternalistic Tory views; ${ }^{104}$ the Factory Acts of 1864 and 1867 extended the principles of factory reform established in the 1840 s, distinguishing between women and young workers who were protected by the legislation, and male workers who remained outside it, "free" to determine their own working conditions. ${ }^{105}$ Arlidge endorsed the view that factory legislation was not necessary for male workers; in his lectures to potters in 1887 he argued that there was no place for conflict over working conditions and called for joint action which would nullify the need for state interference:

Let employer and employed co-operate in every genuine effort to benefit labour, and then the artificial bulwarks of Acts of Parliament will be uncalled for, and artisans will escape that sapping of self-reliance and independence, the fruit of a mistaken confidence in the efficacy of minute educational and restrictive legislation. ${ }^{106}$

His views reflected the tradition of self-help characteristic of mid-Victorian society, ${ }^{107}$ well represented in the Potteries through both the formation of workers' self-help groups, particularly friendly societies, and paternalism among the region's larger employers. ${ }^{108}$ In particular, Arlidge argued that factory legislation could restrict individual freedom by reducing a worker's scope for self-improvement, and that, therefore, the Factory Acts should not be extended to reduce working hours or be too restrictive towards conditions of employment. In Hygiene, he asserted that:

... the Utopian ideas of some reformers could induce the State to act the part of a common parent to the industrial community, and assume to itself the duty of preserving all occupied people from the various ills threatened by their employment, and thereby relieve them [workers] from the duty of self-preservation, of choosing their own place and time of work, and of using their own common senses in avoiding evils they can themselves perceive and guard against. ${ }^{109}$

101 PP 1893-94 xxxIV (Cd. 6894-ix), Royal Commission on Labour, minutes of evidence [Group C Volume III] with appendices, 1, q. 30, 474 to 30 , 513 and q. 30,527 to q. 30,626 .

102 Home Office papers, Dangerous trades: pottery and china, HO45/B12393E/2.

103 Arlidge attended the Evangelical Anglican Parish Church of St George's in Newcastle-underLyme; for a history of the church see John Briggs, St George's Newcastle-under-Lyme, 1828-1978, Newcastle-under-Lyme, St George's Church, 1978.

104 Paul Smith, Disraelian Conservatism and social reform, London, Routledge and Kegan Paul, 1967, pp. 49-51.

\author{
105 Philip Corrigan and Derek Sayer, The great \\ arch: English state formation as cultural revolution, \\ London, Basil Blackwell, 1985, pp. 140-1. \\ 106 Arlidge, op. cit., note 74 above, p. 8. \\ 107 Geoffrey Finlayson, Citizen, state and social \\ welfare in Britain 1830-1990 Oxford, Clarendon \\ Press, 1994, ch. 1. \\ 108 John Briggs, A history of Longton, Keele \\ University, 1982; Dupree, op. cit., note 38 above, \\ pp. 344-5. \\ 109 Arlidge, op. cit., note 1 above, p. 50.
}




\section{Dr J T Arlidge and Victorian Occupational Medicine}

In his lectures to the potters, Arlidge set out to demonstrate that they themselves were in control of their exposure to dust and lead. ${ }^{110}$ Potters, Arlidge advised, should look to their personal habits, particularly alcohol abuse and the consumption of tea, wear proper clothing, ensure that workrooms were well ventilated and, where necessary, wear respirators. ${ }^{111}$

Though Arlidge had turned seventy in 1892, in the years immediately following the publication of Hygiene he continued to contribute to the debate on factory legislation. His expertise as a medical scientist made him an obvious candidate to advise the government on special rules for the pottery industry. At the end of 1892, William Dawkins-Cramp, a Superintending Inspector of Factories, was appointed to investigate conditions in the industry, with particular reference to lead, and to indicate the most pressing needs for reform. ${ }^{112}$ As part of his investigations, Dawkins-Cramp was keen to elicit the views of "probably the best authority on potters' diseases". ${ }^{113}$ Given the tradition that Arlidge represented, it is not surprising that his recommendations for improvement were not drastic. They included the introduction of restrictions on the employment of young workers in occupations that used lead; the extension of safety procedures, such as the use of overalls, to all lead workers; improvements in ventilation; and recommendations on alternatives to the use of lead. ${ }^{114}$ As a result of Dawkins-Cramp's report and subsequent comments made by manufacturers and workers, a Committee was established to investigate conditions of labour in the Potteries. ${ }^{115}$ Arlidge and Spanton were appointed to provide a medical report on the incidence of disease relating to dust, lead and the firing of ware. ${ }^{116}$ Their recommendations were similar to those outlined by Arlidge in his previous communication with Dawkins-Cramp. As a result of this inquiry, the first set of special rules to be served on the pottery industry was introduced in 1894 , mostly referring to measures to reduce exposure to lead-such as provision of overalls and wash basinsas well as procedures for cleaning workshops and basic ventilation requirements, though no recommendation was made to restrict the use of lead. ${ }^{117}$ The Home Office's failure to endorse stricter controls on either lead or the employment of women and young persons was strongly criticized by factory reformers. In particular, the Women's Trade Union League intensified its campaign in the Potteries and continued to gain national support for its endorsement of leadless glazed ware. ${ }^{118}$

Arlidge's role as an expert on potters' diseases did not go without local criticism. In December 1892 he published a pamphlet entitled The pottery manufacture in its sanitary aspects, in which he repeated his call for co-operation between employers and operatives to improve working conditions. ${ }^{119}$ However, the trade paper, the Pottery Gazette, strongly objected to the pamphlet, claiming that Arlidge's description of present conditions was

110 Arlidge, op. cit., note 74 above, p. 7.

111 Ibid., p. 7.

112 PP 1893-94 XVII (Cd. 6978), Annual report of H.M. Chief Inspector of Factories and Workshops, 1892, 65, pp. 41-9.

113 Ibid., p. 45.

114 Ibid., pp. 45-6.

115 PP 1893-94 XVII (Cd. 7240), Report on the conditions of labour in potteries, the injurious effects upon the health of the workpeople, and the proposed

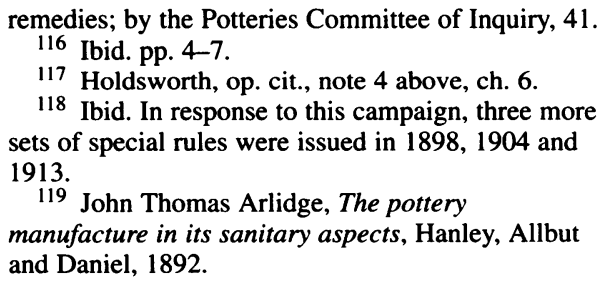


exaggerated and that; as a medical man and an outsider, he knew little about pottery manufacturing. ${ }^{120}$ In reply Arlidge claimed that the Pottery Gazette's criticisms were "few and not weighty", and that his interest in potters' health was motivated by a "laudable desire to arrive at facts from data in which fancy had no part", not by a wish to belittle the industry. ${ }^{121}$ But his defence only served to extend the altercation, and members of the North Staffordshire Chamber of Commerce echoed the Pottery Gazette's criticisms at a meeting in December 1893. ${ }^{122}$ Several manufacturers objected to a lecture that Arlidge had given to the Sanitary Institute in November of that year, in which he drew attention to the failure of pottery manufacturers to address the issue of ventilation. ${ }^{123}$ They accused him of "having shown a grave want of judgement" in delivering the lecture when he was a member of the Potteries Committee of Inquiry. ${ }^{124}$ Arlidge replied as before, stating that his remarks were taken out of context, that they referred to past conditions, and could be applied to "all the great industries in the Kingdom". ${ }^{125}$ By early 1894 the debate was fast losing clarity, and Arlidge continued to protest that his comments were repeatedly misinterpreted by the manufacturers. In February 1894 he wrote:

However, so far as I can judge, my mental equilibrium has not been disturbed by the amount of public notice bestowed upon me; nor has my purpose, to advance the sanitation of the pottery manufacturer, whether by writing or lecturing, been abated by the unjust charges and insinuations levelled at me. ${ }^{126}$

Arlidge also lost support within the community. The local press criticized him, drawing attention to the role that the manufacturers had played in introducing the 1864 Factory Act, so undermining his claim that they could have done more to improve conditions. ${ }^{127}$ Neither did operative potters, who had previously used his work to argue for the introduction of legislation, defend him. Although the Trade and Labour Council thanked Arlidge for speaking out on behalf of the workers, it did not become actively involved in the debate. ${ }^{128}$ Elsewhere, some of his medical colleagues publicly distanced themselves from him. Spanton was so aggrieved by the manufacturers' supposition that he shared Arlidge's views on pottery manufacture because of their joint position on the Potteries Committee of Inquiry, that he sought an apology from the manufacturers which stated that they did not hold him in the same light as his colleague. ${ }^{129}$ In his memoirs, Spanton wrote:

[Arlidge] made an unfortunate beginning to his career as a practitioner by compiling statistics of the people working in the Potteries which gravely reflected on the humanity of the various manufacturers. ... his medical friends [in North Staffordshire] were against him, and up to his death this feeling never entirely died out. He carried out his duties at the infirmary thoroughly well, but his success in practice was never brilliant, owing to his knowledge being theoretical rather than practical, so that his prognosis was often at fault. ${ }^{130}$

120 Pottery Gaz., 1893, 17: 325-6.

121 Ibid., pp. 442-3.

122 Staffordshire Advertiser, 23 Dec. 1893.

123 Pottery Gaz., 1893, 17: 536-7.

124 Staffordshire Advertiser, 23 Dec. 1893.

125 Ibid., 6 Jan. 1894.

126 Arlidge's letter was reprinted in the local press, see Staffordshire Evening Post, 5 Feb. 1894.

127 Ibid., 20 Jan. 1894. The manufacturers' defence of their role in the 1862 inquiry conveniently disguised the fact that the memorial had divided the manufacturing community, and that those who had supported it opposed the extension of the Factory Acts, Dupree, op. cit., note 38 above, ch. 5.

128 Staffordshire Evening Post, 15 Jan. 1894.

129 Staffordshire Sentinel, 21 March 1894.

130 Spanton, op. cit., note 44 above, pp. 38-9. 


\section{Dr J T Arlidge and Victorian Occupational Medicine}

Spanton may have exaggerated the antagonism of fellow medical professionals. Arlidge's position at the infirmary was never questioned; though he had resigned as Senior Physician in 1892, he retained his position as Consulting Physician and remained on the Infirmary's General Committee. ${ }^{131}$ He could also count on the support of local dignitaries not immediately associated with the pottery industry, particularly the Duchess of Sutherland whose husband was Patron of the Infirmary. Arlidge was not by nature antagonistic - contemporaries described him as gentle, a quality reflected in his rather rounded, white bearded and kindly looking appearance-and his altercation with the manufacturers was indicative of poor political skills, which were secondary to his ability as a medical scientist. ${ }^{132}$

However, by the mid-1890s Arlidge was losing his reputation as the national authority on occupational diseases. In October 1895 he wrote to the Home Secretary asking to be considered for a position on a forthcoming committee to investigate dangerous trades. ${ }^{133}$ His request was rejected in favour of a younger doctor, Thomas Oliver, physician at Newcastle-upon-Tyne Infirmary, then establishing his reputation as an expert on lead poisoning. ${ }^{134}$ In retaliation Arlidge was highly critical of the medical content of the Committee's report. ${ }^{135}$ These comments marked the end of his career. In 1897 he contracted peripheral neuritis and retired from work and public life. ${ }^{136} \mathrm{He}$ received some public recognition in his final years. In 1897 he was awarded a civil pension of $£ 150$ in appreciation of his contribution to occupational health, and a committee was formed by some friends to provide him with a testimonial. ${ }^{137}$ Contributors to the fund included a number of local doctors (though not Spanton), Thomas Twyford, the Duke of Sutherland and Thomas Oliver. ${ }^{138}$ Arlidge died on 27 October 1899, aged seventy-seven, leaving $£ 3,857$ to his wife and son, a considerable sum for a provincial doctor.

\section{Conclusion}

At the time of Arlidge's death important advances were being made in occupational medicine. In particular, the Home Office had recognized the importance of medical surveillance of workers and the monitoring of occupational diseases. In 1898 the first Medical Inspector of Factories, Thomas Legge, was appointed. The same year saw the introduction of medical examination by Certifying Surgeons of women and young people working in the pottery industry. ${ }^{139}$ In the early 1890 s the Association of Certifying Surgeons had also been re-established, though Arlidge had nothing to do with the new organization. ${ }^{140}$ In fact he could not claim any direct involvement with many of the advances made. Though Hygiene had initially proved a valuable source to support factory

131 North Staffordshire Infirmary, 75th annual report of the North Staffordshire Infirmary 1889-90, North Staffordshire Medical Institute.

132 Isaacson, op. cit., note 5 above.

133 Home Office papers, Dangerous trades: pottery and china, HO45/9852/B12393E/78.

134 Thomas Oliver (ed.), Dangerous trades: the historical, social and legal aspects of industrial occupations as affecting health, by a number of experts, London, John Murray, 1902.

\footnotetext{
135 John Arlidge, 'Comments on the interim report of the Departmental Committee on Certain Dangerous Trades, 1896', J. sanit. Inst., 1896, 17.

136 Hibbert, op. cit., note 5 above, p. 44.

137 Issacson, op. cit., note 5 above, pp. 10-11.

138 Br. med. J. 1897, ii: 1443, 1460, 1520, 1609,

1672, 1749, 1820, and ibid., 1898 ii: 338, 524.

139 Holdsworth, op. cit., note 4 above, chs 6 and 7.

140 Huzzard, op. cit., note 3 above, p. 112.
} 


\section{Clare Holdsworth}

reformers' claims, Arlidge himself was not regarded as a key player and his death mostly went un-noticed.

Arlidge was quickly forgotten both in North Staffordshire and by twentieth-century experts on occupational health. Writing in 1927 on the history of occupational medicine, Thomas Legge commented that Thackrah's early death in 1833 had "retarded the progress of industrial medicine and surgery for 70 years". ${ }^{141}$ He made no mention of Arlidge's contribution, probably because Arlidge was too closely associated with the traditions of late-nineteenth-century occupational medicine which placed more emphasis on control of workers' exposure to hazards rather than on direct attempts to make the manufacturing process safer. ${ }^{142}$ By the early twentieth century this emphasis on sanitary reform was no longer appropriate. In particular, the introduction in 1906 of compensation for workers affected by industrial diseases highlighted the need for a hazard-free workplace, where any incidence of disease could be regarded as an accident, rather than as an integral outcome of employment. ${ }^{143}$

With the benefit of hindsight, it is all to easy to criticize the belief of nineteenth-century reformers that sanitary measures and co-operation between workers and employers were sufficient to control exposure to such dangerous substances as lead, phosphorus, mercury and silica dust. ${ }^{144}$ However, it is not appropriate to judge Arlidge on twentieth-century criteria and definitions of occupational medicine. He saw a future for occupational medicine very different from that which actually developed. He saw it, not as a discipline concerned mainly with controlling exposure in the workplace, but as an essential part of general practice. But the dominant model of general medical practice remained centred on the family and the home, and the relationship between ill-health and employment was mainly relegated to the narrower specialization of industrial toxicology. ${ }^{145}$

However, Arlidge's contribution to occupational medicine was not ignored by all twentieth-century experts. Oliver, in particular, acknowledged the importance of his work, especially his testimony on occupational respiratory disease. In 1898 he wrote requesting an interview, but Arlidge was too ill to oblige. ${ }^{146}$ Oliver replied that it would give him pleasure to act as his successor and to extend the knowledge and material Arlidge had already accumulated. ${ }^{147}$ Oliver's observations on occupational respiratory disease incorporated Arlidge's contribution to the debate over the role of dust. Writing in 1902 Oliver stated that: "The tendency of modern pathology is to look upon all pulmonary phthisis or consumption as tuberculous, but the fact remains that phthisis can be caused by dust." 148 This was exactly the position argued by Arlidge, and this insistence on the importance of dust remained his most significant contribution to British occupational medicine. Although confusion remained over the precise relationship between tuberculous bacilli and dust, at the beginning of the twentieth century the causal role of dust in

141 Thomas Legge, 'The Chadwick lecture on the teaching of industrial medicine', Lancet, 1927, i: 1115 .

142 Wohl, op. cit., note 6 above, p. 270.

143 Karl Figlio, 'What is an accident?' in Paul Weindling (ed.), The Social history of occupational health, London, Croom Helm, 1985.

144 Wohl, op. cit., note 6 above. p. 270.

145 Paul Weindling, 'Linking self-help and medical science: the social history of occupational health', in Weindling (ed.), op. cit., note 143 above. 146 Oliver to Arlidge, 4 April 1898, Arlidge letter collection, North Staffordshire Medical Institute.

147 Ibid.

148 Thomas Oliver, 'Dust as a cause of occupational disease', in Oliver (ed.), op. cit., note 134 above, p. 272. 


\section{Dr J T Arlidge and Victorian Occupational Medicine}

accelerating fibroid phthisis remained mostly unchallenged. This British view may be compared with that in the United States, where medical knowledge and practice were more heavily influenced by germ theory, leading to a denial of the role of dust in directly causing disease. ${ }^{149}$ Workers in the US had a difficult campaign to achieve medical recognition that silicosis was an occupational disease resulting from exposure to industrial dust. The importance of silica dust in the United States was identified by Frederick Hoffman, an insurance company statistician, who studied the mortality of workers exposed to it and whose findings were directly influenced by Arlidge's Hygiene. ${ }^{150}$

Arlidge does not fit easily into a Whiggish history of progress in occupational medicine; he did not advocate further specialization, nor did he favour more legislation. His lasting contribution to the discipline was distinguished by diligent observation of potters' respiratory diseases which, along with Greenhow's investigations, established the role of dust and the importance of ventilation in factories. He was also one of the earliest advocates of a comprehensive system of medical surveillance in factories. However, to understand his contribution fully we need to see him as a paternalistic Tory, who sought to improve workers' ability to improve their own working conditions by giving them a thorough understanding of the possible health risks associated with their employment. Furthermore, he was a London physician who moved to a provincial town where he successfully established himself as an authority on local medical problems-despite hostility from local manufacturers and some of his medical colleagues-and prompted a number of local and national dignitaries and trade unionists to campaign for improved working conditions in the pottery industry and elsewhere.

149 Rosner and Markowitz, op. cit., note 84 above, $\quad 150$ Ibid., pp. 15-31. pp. 13-48. 